\title{
An Analysis of A Sample of South African University Students' Reflections on Nelson Mandela as a Motivator of Learning
}

\author{
Abongdia, J.A. \\ Galloway, G. \\ Mammen, K.J. \\ Faculty of Education, East London Campus, University of Fort Hare, South Africa \\ Email: jabongdia@ufh.ac.za
}

Doi:10.5901/mjss.2014.v5n14p304

Abstract

The purpose of the research on which this paper rests was to elicit university student's reflections on a then living international icon and examines the extent to which the person and role of Nelson Mandela positively influenced students' motivation. The sample consisted of a group of students in the Post-Graduate Certificate in Education (PGCE) programme. The contents of answers to an assignment in the language module in a narrative writing exercise were found to be worthy of analysis and that is why this is a retrospective study and the students' answers constitute the data. The theoretical framework rests on motivation and the effect of an icon based on modelling theory. The findings led the authors to conclude that the subjects appreciated and valued Mandela's life sacrifices and guidance as an iconic leader of the nation. This in turn has impacted on motivating university students to develop a culture of learning as told and narrated by them.

Keywords: Nelson Mandela, students, learning, motivation, fundamental values, human rights.

\section{Background and Introduction}

This is a research report on a retrospective study which focused on how an international icon as a role model influenced young people in his own nation. The purpose of the paper is to elicit university student's reflections on a then living international icon. It examines the extent to which the person and role of Nelson Mandela positively influenced students' motivation. The data were collected through an assignment in the language module in a narrative writing exercise and the student outputs were the content for analysis. The theoretical framework rests on motivation and the effect of an icon based on modelling theory.

\subsection{The Concept 'Icon'}

It is not new knowledge that the word 'icon' was originally used outside computer-related references to refer to devotional objects such as image, painting, picture, portrait or carving on wood, for example, that of Christ or another holy figure. However, over the years, many influential human beings became famous, powerful, prominent and outstandingly inspiring in certain specific fields such as in liberation struggle, nation building, politics, science, technology, music, art and many others. They became revered in those fields-some in their own countries and others continentally or internationally and came to be known as icons. Some examples of icons of international stature are Einstein (Germany-Science), Gandhi (India-nonviolence), and Mandela (South Africa-racial tolerance and reconciliation). Yet again, some became eminent, well-known, famous and outstandingly inspiring in many areas of human endeavours such as racial tolerance and reconciliation, political leadership, respect for humanity, educational guidance. They became world icons and an illustrious example is the late Dr. Nelson Rolihlahla Mandela, commonly referred to by the indigenous population as 'Tata Mandela', the Father of South Africa. This paper restricts itself to this world icon's influence in the education of many young university students since the birth of post-apartheid and democratic South Africa in 1994.

Dr. Mandela was and still is held in high esteem as a result of the active and committed role that he played in society through the continuous and treacherous struggle as an ardent activist for human rights and equality in South Africa. Before being imprisoned, while in prison for 27 years and then when outside prison as a free man and also as the first President of the 'free' South Africa, he immersed himself in shaping a just society to realise humanitarianism and 
freedom of all South Africans. Through his long struggle against the never-justified or never-justifiable apartheid regime and through leading a human reconciliation model as the way forward in future national conflicts, he earned a positive and profound ripple effect on people, not only in his own nation and his continent but also on the whole world-thus emerging as a world icon.

Mandela was a visionary and was tolerant with respect to conflicts. Liberation struggle slogans from the 1950s in South Africa echoed 'liberation before education' although there always was a conflict between the loud 'liberation before education' and the silent 'education before liberation'. Those in the front row of anti-apartheid fight cherished the former while those in the rear row silently found value in the latter too since there was expectation that the nation needed an educated group of population after liberation.

\subsection{Modelling and role model}

\subsubsection{Modelling}

Modelling occurs when a person's behaviour changes as a result of observing that of another. Within the social cognitive theories, the concepts motivation and learning as consequences of social interaction and imitation gained significance. Bandura and his co-workers worked to define the modelling process and develop a social cognitive theory around the findings by 1986 (Child, 2007). The theory rested on three assumptions. Child (2007) explains these assumptions: (a) there is a triangular relationship between stimulus, person and response; (b) people only demonstrate what they have learnt by imitation when they are motivated to do so; and (c) there are two kinds of learning-enactive and vicarious. Learning through experiencing the consequences of one's own action(s) is enactive learning while vicarious learning is based on observing living or symbolic models without one's overt action.

Child (2007) argues that according to Bandura, exposure to models causes three behavioural change effects: (a) modelling effect-copying an entirely new response pattern not in their behaviour repertoire (b) inhibitory or disinhibitory effects-observing the model may lead the observer to strengthen or inhibit his/her own established responses; and (c) response facilitation or eliciting effect-cues from the model initiates behaviour in an observer.

\subsubsection{A role model}

A role model is a person whose behaviour or success can be emulated by others, especially the young. The term "role model" is credited to sociologist Robert K. Merton (July 4, 1910 - February 23, 2003) who coined the phrase during his career (Wikipedia. n.d.). One of the characteristics attributed to effective models is motivating others. Amongst other characteristics, the most effective were cited as (a) showing competence; (b) similarities between the model and oneself; (c) model's credibility-synergy between what is preached and practiced; (d) model's enthusiasm-glowing in interest in what the model says or does (Child, 2007). Human beings need motivation to attempt to copy others.

\subsection{Motive and motivational theories}

\subsubsection{Motive}

A motive is a factor or circumstance that induces a person to act in a particular way. A motive can originate internally, i.e., factor(s) or circumstance(s) coming from within a person or originate externally, i.e., from another person or external circumstance(s). The former is intrinsic motive and the latter is extrinsic motive. In some cases, one can trigger another and then the internal and external motives act dynamically together, one reinforcing the other. The verb motivate involves supplying the motive or become a motive of an action in a particular way, i.e., trigger or stimulate an action. Motivation is the noun form of the verb motivate. A good motivation should not only trigger or stimulate but sustain the caused action in a constant manner and a dynamic interaction between and amongst both intrinsic and extrinsic motivations is usually needed for such sustainability.

\subsubsection{Motivational theories}

The conceptualization of the word "motivation" can be viewed from different paradigms and theoretical perspectives. In this paper the space is limited to explore the numerous theories on motivation and their limitations although each has its own strengths and weaknesses depending upon the culture, contexts and age groups. Nonetheless, there are certain 
features of the different theories that are relevant to this research. For example, in Maslow's hierarchical theory, love and belonging as well as self-esteem needs are natural for South African university students as contributors to Maslow's highest need of self-fulfilment in making the icon Mandela a role model. Nevertheless, the authors concur with Child (2007) who points out the theoretical and pragmatic challenges associated with the deficiencies in Maslow's needs theory and McDougall's instinct theory. However, the present authors, with respect to university students, are more aligned to motivation in accepting role models in terms of goal-orientated theories where goals and goal-setting are part of growing up. Two pertinent foci of the goals and goal-setting theory are (a) goal choice, i.e., the target set by the individual and the extent of achievement and (b) goal commitment, i.e., the strength of the desire to achieve the chosen goal. Surely, the individual is at liberty to act or not to act either in setting the goal of choice and/or carrying through the commitment. The driving force on both factors towards positive action is enhanced or inhibited by the dynamic interaction between intrinsic and extrinsic motivation and individual differences. The authors acknowledge the influence of both the nature and nurture.

\subsection{Some wise words from the icon focused in this study}

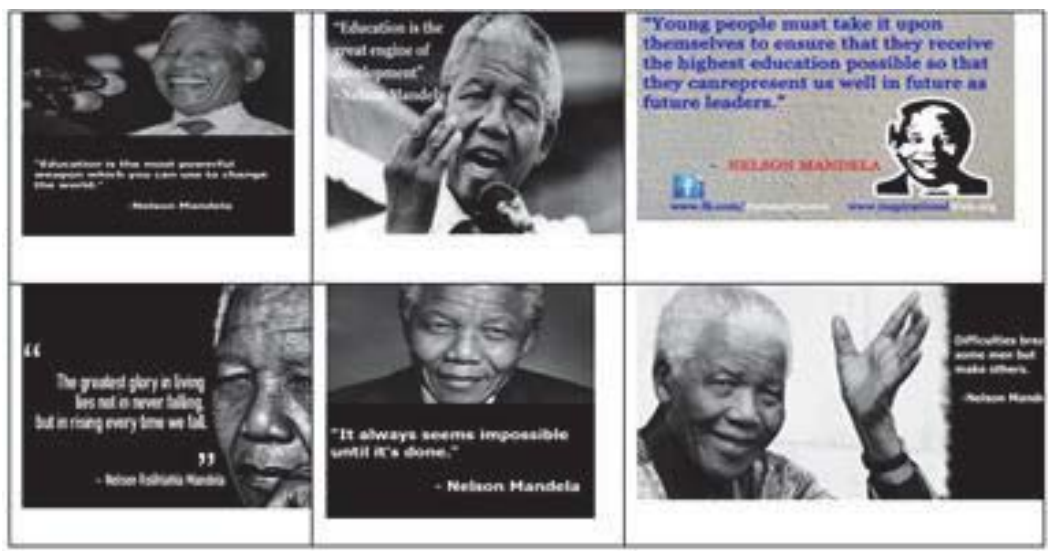

Some of the other Mandela quotes which were and still used in educational and motivational posters promoted by the South African government and other NGOs are given below and one quote is separated from another using semicolon to save space:

Education is the great engine of personal development. It is through education that the daughter of a peasant can become a doctor, that the son of a mineworker can become the head of the mine that a child of farm workers can become the president of a great nation. It is what we make out of what we have, not what we are given, that separates one person from another; Young people must take it upon themselves to ensure that they receive the highest education possible so that they can represent us well in future as future leaders; Education is the most powerful weapon which you can use to change the world; Difficulties break some men but make others; After climbing a great hill, one only finds that there are many more hills to climb; The greatest glory in living lies not in never falling, but in rising every time we fall; I learned that courage was not the absence of fear, but the triumph over it. The brave man is not he who does not feel afraid, but he who conquers that fear.

1.5 The role of Nelson Mandela in the History of South Africa: transition and transformation from a political freedom fighter to a human rights fighter.

Nelson Mandela was born in July 1918 in a small village of Qunu in the Mthatha district in Transkei. As a teenager, Mandela was interested in education and politics and studied law at the University of Witwatersrand and became involved in anti-colonial politics. He was a founding member of the youth league in the African National Congress (ANC), the main Black political party in South Africa. However, his party was later outlawed and banned by the government. The country's ruling party, the National Party (NP), started to implement a strategy of strict racial segregation, later known as apartheid after coming to power in 1948 (Schoemaker 2013). Mandela was steadfast to peacefulness but it is due to the government's ruthless measures against non-violent opposition that he got involved in targeted disruption resulting in many arrests. He became part of a militant wing in partnership with the South African Communist Party in 1961 and was 
eventually convicted of treason and condemned to life imprisonment.

While in prison, Mandela wrote an influential autobiography in secret titled, Long Walk to Freedom. This document detailed his life against the backdrop of deep social injustice and harsh state oppression (Schoemaker 2013). The book was smuggled out of prison in pieces and printed overseas and became a global best-seller and a movie recently. Mandela became the spokesman for a new democratic South Africa.

The most important thing about Mandela is his evolution to the kind of strategic leader he became: from prisons in Robben Island and bringing South Africa to a genuine democracy. He fought for the abolishment of apartheid and stood for free elections and finally became the first democratically elected Black president in South Africa. His remarkable story does not only hold valuable lessons for other leaders but also for students as it is the case in this study to stand firm to morality. This is why the country's emerging political leaders are challenged to build a nation in which all peopleirrespective of race, colour, creed, religion or sex- can assert fully their human worth; after apartheid, South Africans deserve nothing less than the right to life, liberty and the pursuit to happiness (Mandela 1993).

He turned out to be a steadfast committed non-violence activist and fought for human rights. In Mandela's 1994 speech after his election as president of South Africa, he signalled his representation of all the people of his country irrespective of race. A famous part of this speech now inscribed in stone on Robben Island is:

We have, at last, achieved our political emancipation. We pledge ourselves to liberate all our people from the continuing bondage of poverty, deprivation, suffering, gender and other discriminations. Never, never and never again shall this beautiful land experience the oppression of one by another... The sun shall never set on so glorious a human achievement. Let freedom reign. God bless Africa.

Mandela's main focus was to encourage racial harmony, forgiveness without forgetting, power sharing and a strong focus on the future, and not the past. This he supported by being generous to his former enemies. He greatly sacrificed and in the process he eventually became a world icon for human rights. He was of course a great transformational leader and a remarkable man. He encouraged and stood for education as he said: "Education is the most powerful weapon which you can use to change the world". This is echoed by most of the students in this study who think and argue that Mandela motivated and created an opportunity for them to study". Nelson Mandela died in December 2013 and was duly given a full state funeral as an icon of South Africa and the world.

\subsection{Mandela as a motivator}

Another important concept to be considered in this paper is Mandela's role as a motivator. The quotes cited earlier are clear evidence of this since motivation is a stimulant, something that energizes, directs, and upholds behaviour. Motivation drives everyone including students to go with a focus in a particular direction, and keeps them encouraged. Students' motivations are mostly seen to be reflected in personal investment and in cognitive, emotional, and behavioural engagement in school activities (Fredricks, Blumenfeld, \& Paris, 2004; Reeve, 2006). Commonly, almost all students are motivated in one way or another. However, motivation is not necessarily something that learners bring to school; it can also arise from environmental conditions at school (Paris \& Turner, 1994; Rueda \& Moll, 1994). Looking at the environment and how it enhances learners' motivation to learning or behaving in particular ways refers to situated motivation (Paris \& Turner, 1994; Rueda \& Moll, 1994).

\subsection{Motivational impacts}

Leithwood and Montgomery (1984) explored the relationship between motivation to effective leadership and school goals as they focus on the principal motivation of becoming a more effective leader while students are motivated to learn. Of the stages to become a good leader, Leithwood and Montgomery significantly bring out the notion of humanitarian in the second stage among staff, where they cultivate good interpersonal relationships. This is the core of this paper, as it looks at Mandela and the role he played in motivating students to learn as will be seen in the discussion. At the fourth stage, Leithwood and Montgomery (1984) echo the notion of "problem solver with a devotion to a legitimate, comprehensive set of goals for students and seek out the most effective means of their achievement" (p.51).

\subsection{A variety of names for Mandela which South Africans passionately use}

Isixhosa is one of the official South African languages and is one of the most spoken and written local language. Almost all the residents of Mandela's home province (Eastern Cape) speak isiXhosa. His birthname 'Rolihlahla'(given by his father) meant "pulling the branch of a tree", but colloquially, it meant 'trouble-maker' which he was for the apartheid South 
African government later in his life . His first school teacher gave him the first christian name Nelson. Madiba was the his clan's name which originated from the name of an $18^{\text {th }}$ century Tembu tribal chief and many people call him as Madiba passionately. Many people, regardless of their own age, called Mandela "Tata" - an isiXhosa word meaning 'father' since for them, he was a father figure and someone they looked up to. Interestingly, although he was addressed as Tata (father) even when he was a political prisoner, it turned out that he became the 'Father of Nation' of South Africa. Sometimes, people also used combination of two names such as 'Tata Madiba'.

\subsection{Nelson Mandela Day and 67 minutes}

Since the methodology refers to 67 minutes, a brief background to Nelson Mandela day and the pertinence of the specified number of minutes may be appropriate here. The authors thought that it would be ideal to extract quotes from formal websites.

Mandela Day has been officially adopted by the United Nations as "Nelson Mandela International Day". The resolution was unanimously adopted on November 10, 2009, with the support of all UN member states and cosponsorship of over 165 members, from all regions of the world. This represents the overwhelming support of the entire international community in honouring the late Mr Mandela. ... Mandela Day is an annual international day of humanitarian action in celebration of the late Mr Mandela's life and legacy. It serves as a catalyst for each and every person to realise that they have the ability to change the world through action. ... The Elders - a group of eminent global leaders founded by the late Mr Nelson Mandela - have joined the late former president of South Africa in a special message of support for Nelson Mandela International Day. In a video message shot during the Elders' last visit to South Africa in June 2010, they urged people everywhere to give 67 minutes of their time to reach out to others in their communities (Flow Communications, 2014).

According to United Nations,

Every year on 18 July - the day Nelson Mandela was born - the UN joins a call by the Nelson Mandela Foundation to devote 67 minutes of time to helping others, as a way to mark Nelson Mandela International Day. For 67 years Nelson Mandela devoted his life to the service of humanity - as a human rights lawyer, a prisoner of conscience, an international peacemaker and the first democratically elected president of a free South Africa" (United Nations, n.d.).

\section{Methodology}

The methodology required the analysis of the reflections of Postgraduate Certificate in Education (PGCE) students in an assignment at one university in South Africa. The assignment took place during the annual 67 minutes dedicated to serving society which has become an international 67 minutes of giving of one-self through various forms of displaying Mandela's magnitude on the world. The lecturer aligned the 67 minutes to the effectiveness of such opportunities as innovative teaching and learning, focusing on a particular icon, who has his roots deeply entrenched in the Eastern Cape, his birth province where the university was also located. The analysis was carried out within the context of the dominant ideologies amongst the students in terms of the role played by Nelson Mandela in motivating the students' learning. Thus a qualitative research method was used, were written reflections were analyzed in order to determine the current ideological positions with regards to how effectively Mandela motivated student's learning. The data for this study were collected through a given assignment for students to reflect on the life of Nelson Mandela and the role he played in their lives. This study made use of 40 reflections written by the students.

The data were analyzed qualitatively through the use of written responses to a topic using Critical Discourse Analysis to see how different experiences and motivations were constructed by different respondents. Since the data were mainly in the form of transcripts extracted from students' answers, they are quoted and discussed in the next section.

Furthermore, following Besemeres (2006) and Dewaele (2006), note was taken of the number of occasions when particular lexical items, especially those of strong emotional content, were used by some of the respondents such as: Freedom; selfless; sacrificial lamb; courage; suffering. In addition, careful note was taken of the respondents' tone in their writing and the manner in which the information was presented: emotionally, happily, jealously or passionately.

\section{Discussion and Findings}

The findings from this study show that Nelson Mandela played an instrumental role in motivating students' learning at the University under focus. While some students were motivated to learn because of the sacrifices made by one of the 
world's greatest icons, who spent 27 years in jail fighting for the liberation of his country, others thought of Madiba's continuous spirit of learning even when in prison. Drawing from the reflections of the students, one of the students wrote:

My hope is that Mandela's attitude has influenced those around him, especially those in power to live a life of a true leader, one that has a heart to serve and is humble in all they do. I have learned from this strong man to use my energy until the very end to make a positive impact in this like...to meet every challenge with courage and good attitude.

According to this student, Nelson Mandela has not only influenced leaning but has affected the socio-political situation of the country. This is not an individual view but a common idea that cuts across a majority of the analysed reflections. This, thus takes us to Ricento's (2006) notion of a "commonsense knowledge". Therefore, because ideologies are commonly shared, they have great effects on the policy of a country. Ricento further adds that to better understand how practices are interpreted and supported or opposed by the dominant group in the society. As such, we need first of all to understand that ideas and beliefs become ideologies and that these ideologies provide frameworks for the interpretation and practices of the majority group. The question here is, how South Africans in general and university students in particular hold the view that Mandela had been of great influence in their lives. He positively influenced their academic careers. Hence, some of the students believe, as stated in their own words below, that,

Tata is the sacrificial lamb, the lamb of the nation that lost its life for the freedom of all South Africans. When I think of Mandela, I see that unfinished agenda, I see a future crisis given the current politics... I wish I could have some of his wisdom and use that wisely... I wish I could be blessed with the strong will and courage to stand for the right thing that Madiba stood for....

We have an educational system that caters for everybody in this country today thanks to Madiba. Everyone has the right to education in our days and this is what he fought for. His fight for education has brought social transformation by redressing the imbalance in the past while paving a way for a rainbow nation with diverse culture, peace and unity.

If one considers words like "sacrificial lamb" "freedom" "politics" "will and courage", one ought to also think of oppression, suppression, dictatorship and political upheavals in the pre-1994 apartheid era. Thanks to the world icon, Nelson Mandela, words such as oppression, suppression, dictatorship disappeared from public discourse and peace, democracy and human rights started reigning. Blacks not only became able to pursue education as it is the case with most of the students in this study but also many bursaries became available. Worth noting is the link between the students' views and Madela's view quoted earlier that education does not discriminate, "the daughter of a peasant can become a doctor".

\begin{abstract}
After the release of Madiba, we were able to go to school especially with free education as we were not able before because of all the responsibilities that prevented us to afford tertiary education. Tata Madiba was and is still an inspiration that although I am not young, I am still studying as he studied while in prison.
\end{abstract}

I want to bring change to those I touch as Madiba brought it to us. I take off my hat to this man that spent a good portion of his life in prison so that we are saved.

It is thanks to Mandela that I am a student at (this) University today. Were it not for him, I am sure a sign of Whites only would have been the bill board over this place.

It is important to note that Nelson Mandela did not only fight for democracy but also for a great change in mindset. What he said about education quoted below changed university students' mindsets, "... education is the great engine for personal development" and "... education is the most powerful weapon which you can use to change the world". These are echoed by the students' words in this study as seen in the extracts above. There is of course no doubt that many students will follow his ideals too..

As Leithwood and Montgomery (1984) argue, the relationship between motivation to effective leadership and school goals are very instrumental in the academic success of students. They view the principal motivation of becoming a more effective leader as a great force that motivates students to learn. This was no doubt echoed by some of the students in their reflections:

In his time, he encouraged children to go to school. He also wanted to see an improvement in disadvantaged rural areas because he treated all people equally. 
Tata Madiba was and is still an inspiration that even though I am not young I can still study as he studied while being imprisoned. I applied for a bursary and was accepted. I told myself that I was going to give it my all and get the degree as a token of appreciation for what he and others fought for all these years.

Being a selfless man, Madiba won the hearts of many, including students at the institution of this research focus, who feel indebted to him, a great motivation to learn and to uphold all that their predecessor started. The students appreciated the fact that they were able to study and will of course be responsible to their peers.

Tata Madiba was not doing what was good for him and his family but he was doing what was best for the nation. I thank him because today I am a student, I do not pay any school fees because of him. Madiba, I will do the best for my learners and for myself because of you.

This confirms what Nelson Mandela in one of his speeches at the University of the Western Cape in 1990 said: "The challenges are enormous and the tasks ahead may appear daunting. But, the future of our country and our people beckons us all to great deeds. Let us move forward with vision, with courage and determination as we educate for empowerment."

Another motivation towards learning highlighted by the students is that Mandela used part of his salary for the education of the nation's children. This in one way or the other motivated the students not only to go to school but also to work very hard to be better their lives.

Mandela is a symbol of love. He loved people that he wanted a better life for everyone. He encouraged people to educate themselves and to empower themselves through knowledge. He used a third of his salary to fund the children's trust fund and believed in educating and empowering children so that they may grow up to be all that they can be in life.

It could be noted that most of the students were positive towards learning - thanks to the great role Madiba played towards the socio-political and economic development in South Africa. Although most of the students were young before and the mid 1990s and did not experience the oppression of the apartheid regime which their parents suffered, the effects seem to live with them by default. However, there were some elderly students in class who only had the opportunity to study when Nelson Mandela took over power.

\section{Conclusions}

While the life and political drive of Nelson Mandela might be questioned by a few, it is indisputable that he did not only affect the political situation in South Africa but influenced and shaped the socio economic and most importantly the academic lives of South Africans in general and university students in particular. This resulted from the many years of apartheid era of suppression and oppression and the resulting marginalization of the Blacks. From the data, it was found that students became interested in learning and were motivated to advance in education due to the torments Mandela went through to set them free from the apartheid regime.

This paper provided an analysis of how Nelson Mandela motivated learning through his influence in the historical, socio-political and economic realities of South Africa and his part as a role model. This had a positive impact on the students' success. The role of Mandela remains distinct in the academic success of the students as echoed in the reflections where they openly expressed loyalty and great appreciation to the world icon Tata Madiba.

\section{References}

Besemeres, M. (2006). Language and Emotional Experience: The Voice of Translingual Memoir. In: A. Pavlenko (ed.) Bilingual Minds: Emotional Experience, Expression and Representation. Clevedon: Multilingual Matters.

Child, D. (2007). Psychology and the Teacher. New York: Continuum International Publishing Group.

Dewaele, J. M. (2006). Expressing Anger in Multiple Languages. In A. Pavlenko (ed.) Bilingual Minds: Emotional Experience, Expression and Representation. Clevedon: Multilingual Matters.

Fredricks, J., Blumenfeld, P. and Paris, A. (2000). School engagement: Potential of the concept, state of the evidence. Review of Educational Research, 74, 59-109.

Flow Communications. (2014). http://www.mandeladay.com/static/international-involvement. Retrieved 30 April, 2014.

Leithwood, K. A., and Montgomery, D. J. (1984). "Patterns of Growth in Principal Effectiveness." Paper presented at the American Educational Research Association Annual Conference, New Orleans, Louisiana, April 23-27, 1984.

Mandela, N. (1993). South Africa's future foreign policy, Foreign Affairs, 72 (5). http://www.safpi.org/news/article/2013/nelson-mandelasouth-africas-future-foreign-policy. Retrieved 30 April, 2014. 
Nelson Mandela Foundation (2014). http://www.nelsonmandela.org/content/page/names. Retrieved 06 May, 2014.

Paris, S. \& Turner, J. (1994). Situated Motivation, In P. Pintrich, D. Brown, \& C. Weinstein (Eds.),Student Motivation, Cognition, and Learning. Hillsdale, NJ: Lawrence Erlbaum Associates.

Reeve, J. (2006). Extrinsic rewards and inner motivations. In C. Weinstein \& T. L. Good (Eds.), Handbook of classroom management: Research, practice, and contemporary issues (Chpt. 24, pp. 645-664). Hillsdale, NJ: Lawrence Erlbaum.

Ricento, T. (2006). Americanization, Language Ideologies and the Construction of European Identities. In Mar-Molinero, C. and Stevenson, P. (eds.) Language Ideologies, Policies and Practices. Language and the future of Europe. Palgrave: MacMillan.

Rueda, R. and Moll, L. (1994). A sociocultural perspective on motivation. In H. F. O'Neil,

Jr. \& M. Drillings (Eds), Motivation: Theory and Research (pp.117-137). Hillsdale, NJ: Lawrence Erlbaum.

Schoemaker, P. J. H. (2013). Lasting Legacy: Nelson Mandela's Evolution as a Strategic Leader http://knowledge. wharton.upenn.edu/article/lasting-legacy-nelson-mandelas-evolution-as-a-strategic-leader/ Retrieved 30 April, 2014.

United Nations. (n.d.) Welcome to the United Nations. It's your world, http://www.un.org/en/events/mandeladay/ Retrieved 30 April, 2014.

Wikipedia. (n.d.) Role Model. http://en.wikipedia.org/wiki/Role_model. Retrieved 06 May 2014. 